\title{
FORTY YEARS OF THE CONSTITUTION AND ITS VARIOUS INFLUENCES: JAPANESE, AMERICAN, AND EUROPEAN
}

\author{
Yasuhiro OKUdaIRA*
}

I

Introduction: An Observation of the Legacy of the Old Constitution

A few months ago when I was in West Berlin, I had an opportunity to talk with a German lawyer. Our conversation went like this: He said to me, "I understand that you are a public law professor. What field are you most interested in?" "I have been particularly interested in the field of free expression," I replied. "Aha, that is the field which is covered by Article 5 of our Constitution," the German lawyer stated. "That's right," I told him. "Whereas freedom of expression is protected by Article 5 of the Bonn Grundgesetz, the same protection is provided by Article 21 of the Japanese Constitution." The German lawyer commented, "That is to say, your Article 21 corresponds to our Article 5." A bit puzzled, he asked me, "But why does such an important institution as free speech come on the stage in such a sidetracked manner?"

At first glance, his question seems to be concerned merely with the form or shape of the Japanese Constitution. But I do think that there is more to his question than that. The order of constitutional provisions establishing or guaranteeing concepts and institutions is inevitably determined by the ideas and theories that have driven the nation to making a constitution. The order of provisions is a reflection of the value system of the makers of the constitution.

Now I had to try to explain to the German lawyer why freedom of expression in Japan is constitutionally guaranteed by Article 21 rather than by Article 5 or by even earlier articles. I did it as follows:

While the first chapter of the German Constitution deals with the guarantee of various basic rights (Grundrechte), the first chapter of our Constitution is concerned with the tenno or emperor system, which is followed by the so-called "pacifist" or "peace" clause, Article 9. Article 9 by itself makes up the second chapter. Then, our Bill of Rights makes an entrance in the form of the third chapter, and of course, Article 21 is in this chapter. If those who make a constitution put at the beginning of the constitution what they deem to be the most important, the respect and guarantee of

Copyright $(1990$ by Law and Contemporary Problems

* Professor, Faculty of Law, University of Tokyo. 
fundamental rights were regarded as paramount by the founders of the German Constitution. But in the case of the Constitution of Japan, it was a bit different. Our founders seem to have considered that the most important thing to do in terms of the business of making a constitution was to let the tennō system survive, and preserve it much as it used to be under the old constitution.

I concluded my observation by saying, "The sidetracked treatment of the freedom of expression in our Constitution can be understood only in relation to the survival of the tenno system or the legacy of the old constitution."1

At present, more than forty years after the promulgation of our Constitution, it is quite an arguable question whether the tenno system still occupies a real, pivotal position in the constitutional regime, and whether the people still regard that system as one of the most important institutions of government. I believe that the role that the tenno is expected to perform has gotten considerably smaller-far smaller than expected at the time of the promulgation of the new Constitution, and that the people in general have become accustomed to the tenno- playing such a small role. It should be understood that the intention of the founders of the Constitution that the tenno system be an integral part of the Constitution, and as such perform politically meaningful functions, did not come to be realized. This goal for the tenno system, which was contemplated by the elite, was largely neglected in the process of constitutional development. However, we should keep in mind the historical fact that the founders were almost fanatical about insisting that preservation of the tenno system be the most important aim of the Constitution.

I have been referring to the constitutional founders, among whom the Supreme Commander of the Allied Powers ("SCAP") and his staff were included. It is a well-known fact that lawyers working for the Government Section of SCAP took the initiative in drafting the Constitution. As a matter of fact, the plan that a chapter dealing with the tenno system would come first originated in the so-called "MacArthur draft" of the Constitution rather than from any explicit demand of the Japanese Government. General MacArthur decided that it would be better for SCAP and for Japanese society to keep that system alive in a modified and weakened form and to utilize it to recover from the severe war damage. Needless to say, the idea of the survival of the tenno system concerned the Japanese Government immeasurably, since it had been afraid that it would be forced to abolish the tenno system altogether.

1. Perhaps some of you are puzzled with the term tennō. Emperor is the English translation of tenno and the usage of emperor prevails throughout the world. (In Germany, they refer to tenno as kaiser. Kaiser exactly corresponds to emperor.) The use of the word emperor as connoted by tenno originates from the official English text of the Meiji Constitution. The original title of the Meiji Constitution is The Constitution of the Empire of Japan. As I understand it, empire should be, as with the Holy Roman Empire or the British Empire, more than a mere kingdom. I do not think that the definition of empire could be applicable to the Meiji state, but its constitution proclaimed it to be an empire. To that extent, under the Meiji Constitution, the word emperor, corresponding with the expression empire, is perhaps appropriate, if not accurate. However, the Empire of Japan came to naught after World War II. The Empire was gone. Thus, for example, imperial University of Tokyo became merely University of Tokyo. Without the Empire of Japan, there is no basis for calling the tenno- "emperor." 
The constitutional modification of the tenno- system was done in a wholesale manner. We can say that it was almost revolutionary. Sovereign power that had resided in the tenno system was now transferred to the people's hands. ${ }^{2}$ Why, then, did the founders dare to assign that modified institution to the first chapter in the text of the Constitution? The reason is very simple: They just followed the way of ordering chapters found in the old Constitution. Once they determined the survival of the tenno system, they felt that it would be better to have the appearance of continuity from the Meiji Constitution to the new Constitution. In the Meiji Constitution, the first seventeen articles were devoted entirely to the tenno himself. This structure was most appropriate to the Meiji Constitution, the aim of which was to establish the principle of tenno-above-all. It was natural, even necessary, for the old Constitution to begin with the tenno.

It is well known that the Meiji Constitution, promulgated in 1889-exactly one hundred years ago-was made under the strong influence of the Prussian Constitution of 1850 . This is true to a great extent. However, so far as the placement of the tenno clauses of the Meiji Constitution is concerned, no such influence can be seen. In the Prussian Constitution, the first chapter (Title I) deals with the state territory, which is followed by the second chapter (Title II), "concerning the rights of the Prussian People." Only in the third chapter (Title III) do provisions appear "concerning the Crown" (Articles 43-59). This fact indicates that the Prussian Constitution was not free from the impact of the 1848 revolution and the Frankfurt (Pauls-Kirche) Constitution of 1849. Of course, the draftsmen of the Meiji Constitution did not like that aspect of their Prussian model and, instead of copying that aspect of the Prussian Constitution, they adopted the style of the constitutions of such southwestern states as Bavaria (1818), Baden (1818), Württemburg (1819), and Hessen $(1820) .^{3}$

2. However, it should be noted that the draftsmen of the Constitution tried everything, as I shall emphasize in the text, to conceal the appearance of this characteristic of the "revolution." For example, Article I of the 1947 Constitution reads, "The Emperor [tenno in my terminology] shall be the symbol of the state and of the unity of the people, deriving his position from the will of the people with whom resides sovereign power." The construction of this Article is highly sophisticated. This single sentence combines two different matters into one. On one hand, it discusses the status of the tenno and gives a constitutional basis for the tenno system. On the other hand, it explains the location of sovereign power, or, rather, it implies the transfer of sovereign power from the tenno to the people. At any rate, Article 1 is a delicate, complicated sentence.

3. Details of these constitutions vary. Some dealt first with the territory or general characteristics of the states concerned and then with the Crown and the royal family; others referred first to the crown as the Oberhaupt (head) of the state. The Belgian Constitution of 1831 -in addition to the Prussian Constitution of 1850-influenced the Meiji Constitution. However, there is a vast difference between the Belgian and the Japanese Constitutions with respect to the style of the provisions concerning the Crown. It is fair to say that the present Constitution, in following the style of the placement of the tenno clause of the Meiji Constitution, is modeled on early nineteenth century constitutions of southwestern German states rather than the 1850 Prussian Constitution. 
II

\section{The TENNŌ-A Minimal Institution and Its Effects}

In the Introduction, I pointed out an aspect of backwardness inherent in our Constitution. Here, I briefly trace and clarify how this aspect has revealed itself during the past forty years or so, beginning with a discussion of lèse majesté.

Book II of the Criminal Code of $1907,{ }^{4}$ entitled "Crimes," indicates the types of crimes and their corresponding penalties. In 1947, the first Chapter of Book II dealing with special crimes committed against the tenno and the Royal Family was abolished. ${ }^{5}$ High treason against the tennō, lèse majesté, was done away with at that time. Before and during the war, Article 74, providing for lèse majesté, had been heavily utilized as a powerful weapon against political dissidents.

Immediately following the surrender, a disastrous situation prevailed throughout the country. Food was extremely scarce. Public demonstrations against government policies were organized in various cities. One day in the spring of 1946, a protest demanding food provisions was held at the Palace Plaza in Tokyo. One participant carried a placard stating: "Imperial edict of Hirohito: The national polity is maintained; we, the Sovereign, are eating our fill; ye, our subjects, be starved and die! The Imperial Signature and Seal."'6

The Government deemed that the placard constituted lèse majesté and indicted the man. On November 2 of the same year, the Tokyo District Court found him guilty, but on the basis of the regular defamation law ${ }^{7}$ rather than of lèse majesté. Interestingly, the very next morning, a decree of general amnesty $^{8}$ was issued, which immediately pardoned anyone who had been found guilty of lèse majesté. The defendant, however, appealed the case to the Tokyo High Court seeking a declaration that he was not guilty. In June 1947, the high court dismissed the appeal on the basis of the amnesty decree, without hearing the merits of the case. The case went to the Supreme Court, which in May 1948 affirmed the high court's decision, again, without hearing the merits of the case. ${ }^{9}$

The new Constitution, which had not even been promulgated at the time of the trial, came into effect in May 1947, and, therefore, was applicable to the case in the second and final instances. If the new Constitution were applicable to this case, it was arguably the case that the provision of lèse majesté-a very special, criminal defamation clause-was in contravention of Article 14 of the Constitution, which required equal protection of the law. In fact, the

4. Keihô (Penal Code), Law No. 45, 1907.

5. Law No. 124,1947

6. Translated into English and quoted in Supreme Commander of the Allied Powers, Political Reorientation of Japan, September 1945 to September 1948, at 240 (1949).

7. Penal Code arts. 230, 230(2); see infra note 79.

8. Imperial Order No. $511,1946$.

9. 2 Keishū 529 (Sup. Ct., G.B., May 26, 1948). Decisions of the Tokyo District Court and the Tokyo High Court are printed in 2 Keishū at 603. 
defendant asked the courts to consider the question of constitutionality on this point. However, as we have seen already, neither the high court nor the Supreme Court accepted the defendant's invitation, and, instead, both dismissed the case on the basis of the amnesty decree. The courts preferred to avoid a constitutional issue.

While the placard case was pending before the high court, SCAP tried to persuade the Cabinet to prepare a draft deleting entirely the first Chapter of Book II of the Criminal Code. ${ }^{10}$ General MacArthur insisted that since the tennō had declared himself a natural human being rather than a divine being, special legal treatment of the tenno- and the royal family should remain only as minimally necessary, and that, for this reason, the first Chapter of Book II should be abolished. Prime Minister Yoshida firmly opposed General MacArthur, maintaining that any harm to the tenno would be against the interest of the state. Since the tenno was regarded as the central figure of the Japanese people's moral respect, he and the royal family should be entitled to the special protections extended by the first Chapter of Book II. SCAP was, of course, powerful enough to insist upon its demand for the deletion of the first Chapter of Book II. ${ }^{11}$

One can imagine how reluctant the Japanese Government, including the judicial court, was in liberating the people from the traditional tenno regime. However, once the new Constitution replaced the old one, the Government lost legal support for its conservative position and was forced to accept the change. Almost all prewar, special laws concerning the tenno were abolished. Instead, only a few laws were newly enacted to implement certain constitutional provisions. ${ }^{12}$

The very Constitution which has bequeathed to the nation the tenno system-a somewhat anachronistic institution, I venture to say-also declares in its Preamble a lofty principle of democracy reminding one of President Lincoln's Gettysburg Address. ${ }^{13}$ It has been established for forty years that

10. Chapter 1 of Book II, entitled "Crimes Against the Imperial House," consisted of four articles. Article 73 was a capital punishment clause against anyone who had inflicted or had been about to inflict physical harm upon the emperor, the empress dowager, the empress consort, the prince imperial, or the eldest grandson of the emperor in the direct line. Article 74 imposed a criminal sanction on anyone who had committed an act of an insulting and disrespectful nature against any person listed above or against their holy settlements. Articles 75 and 76 were similar provisions protecting other members of the Imperial House.

11. See Shiro Haga, Nihon Kanri no Kiko to Seisaku, in Yuhikaku 93-94 (1951). As for lèse majesté in Japan, see generally L. Beer, Freedom of Expression in JAPAN 48, 53, 77-80 (1984).

12. Major legislation in this field is as follows: the Imperial House Law, Law No. 3, 1947; the Law Concerning Fiscal Matters of the Imperial House, Law No. 4, 1947; the Law Concerning Ad Hoc Deputations of Royal Performances, Law No. 83, 1964; and the Law of the National Calendar, Law No. $43,1979$.

13. The Preamble of the Constitution of Japan declares:

We, the Japanese people . . do proclaim that sovereign power resides with the people and do firmly establish this Constitution. Government is a sacred trust of the people, the authority for which is derived from the people, the powers of which are exercised by the representatives of the people, and the benefits of which are enjoyed by the people. This is a universal principle of mankind upon which this Constitution is founded.

1947 Const. preamble. 
this principle of democracy is one of the three constitutional principles-the other two are the principle of world peace, or pacifism, and the principle of the protection of fundamental human rights.

The tenno system, which was the most controversial issue at the time of the enactment of the new Constitution, remains alive as only a minor institution in the constitutional constellation. It is now nothing more than an accessory to democracy. ${ }^{14}$

\section{III}

\section{American Influence upon the Constitution of JaPAN}

While Chapter 1 deals with the tenno, Chapter 2 is entitled "Renunciation of War." The question of who took the initiative in inserting this Chapter (which consists of a single clause, Article 9) in the text of the Constitution has provoked a great deal of discussion. But, for my present purpose, it suffices to say that there exists no American constitutional influence upon either Chapter 1 or Chapter 2.

Apart from these examples and several other instances, the influence of American constitutionalism is evident and decisive. In the following paragraphs in this section and in section IV, I would like to provide an overview by showing three aspects of significant American influence on the 1947 Constitution: the ideas of democracy, individual rights, and judicial review.

\section{A. Idea of Democracy}

The single most important contribution of the United States Constitution to that of Japan was the concept of democracy. The predominant characteristic of the Meiji Constitution was its so-called ScheinKonstitutionalismus, or pseudo-constitutionalism. The political system of prewar Japan was a modernized version of an absolute monarchy, and the concept of democracy was regarded as unadaptable to Japan. This is why it was constitutionally impossible, or would at least have been extremely difficult, in the prewar years to democratize the political system of Japan in the sense of "government by the people's consent," even though a bicameral parliamentary system, more or less similar to the Westminster type, had been adopted and practiced for the sake of appearance.

In marked contrast, the present Constitution clearly declares that sovereignty resides in the people. Thus, the idea of democracy should and can be applied and can penetrate without reservation throughout all the affairs of government.

14. I believe that being merely an "accessory" is not only recognized in a normative sense but also in the general perception of the people. Of course, many people think the tenno should be even more of an accessory. Furthermore, there always remains a question as to what type of accessory is desirable, appropriate, or necessary. Recently, during the end of 1988 and the beginning of 1989 , we witnessed an outburst of divided discussions from the time of Hirohito's death to Akihito's assumption of office. 
With respect to the political scheme, however, the Constitution prefers a British-style, parliamentary-cabinet system; it does not adopt the presidential system and the strict separation of powers of the American model. The Constitution provides for a bicameral system, stating in Article 43 that " $[t]$ he Diet shall consist of two Houses, namely the House of Representatives and the House of Councillors." In its bicameral appearance, the Diet is the same as the British Parliament. However, while members of the British House of Lords are not elected by the people, but are appointed by the Crown instead, the Japanese House of Councillors, as well as its House of Representatives, "shall consist of elected members, representative of all the people."15

Interestingly, the so-called MacArthur Draft intended to introduce unicameralism. ${ }^{16}$ SCAP's position seemed both simple and persuasive: The British type of bicameralism-which served as the model of the Diet system of the Meiji Constitution-is not wholly democratic. Since Japan has a unitarian type of government, there would not be any basis for adopting the American type of bicameralism unique to its federal system. Therefore, bicameralism would be redundant.

However, the Japanese Government did not like the idea of unicameralism. Enumerating certain merits of bicameralism, the Government requested that SCAP change its position. SCAP accepted this request on the condition that the members of each House be elected by the people and represent all the people. As a result, Article 43 of the present Constitution was adopted. ${ }^{17}$ However, this provision created a new problem: how to distinguish the House of Councillors from the House of Representatives.

While the Japanese founders were sticking to the ideas of bicameralism and a House of Councillors in addition to a House of Representatives, one possible method of distinguishing the two was contemplated: introducing a house of vocational representation similar to the system of the two Councils of Labor and of Management in the 1919 Weimar Constitution. ${ }^{18}$ Moreover, the wording of Article 43, clause 1 , is a bit ambiguous. It raises a question whether that clause permits some sort of "indirect election" to select members of the House of Councillors. Immediately after the Constitution became effective, there were some who argued that "indirect election" was permissible and desirable in terms of the House of Councillors' membership. But there has been no attempt to replace the existing direct popular-vote system with such an indirect election.

If the election system is the same between the two houses, what other distinctions should exist between them? The Constitution has several

15. 1947 Const. art. 43 .

16. Article XLI of the Draft states that "[t]he Diet shall consist of one House of elected representatives with a membership of not less than 300 nor more than 500." Takayanagi, Otomo \& Tanaka, Nihonkoku Kempó Seitei no Katei, in 1 Yūhıkaku 282 (1972). The approval of the nobility, a prerequisite for the prewar House of Peers, MeIjı Const. art. 34, should no longer exist under the new Constitution. 1947 Const. art. 14(2).

17. Takayanagi, Otomo \& Tanaka, supra note 16, at 197-99 (vol. 2).

18. Der Arbeiterrat and der Wirtschaftsrat, art. 165 of the Weimar Constitution of August $11,1919$. 
provisions that make the House of Representatives superior to the House of Councillors in such political matters as legislation, ${ }^{19}$ the enactment of treaties, ${ }^{20}$ and the appointment of the Prime Minister. ${ }^{21}$ Besides these provisions, the Constitution does not say much about the differences between the powers, functions, or roles of the two Houses. Thus, this problem of determining any differences is left to legislative solution. If the House of Representatives is treated as a fixed star, the question can be phrased in relation to the House of Councillors. For example, how is that House distinctive? How do we differentiate it from the House of Representatives? What role is it expected to play in parliamentary deliberation? This is the "House of Councillors Question."

This problem developed as a result of the Japanese Government's refusal of the MacArthur draft. I sometimes wonder what would have happened in the postwar political process if Japan had introduced unicameralism. ${ }^{22}$

\section{B. Protection of Individual Rights}

The influence of the United States Constitution has been decisive in the field of protecting individual rights. The Constitution of Japan has adopted various legal concepts based on the unique American concept of individualism, including the notions of freedom and equality, and provides a comparatively detailed list of "fundamental human rights." The very term "human rights" calls to mind the American idea of civil liberties with a natural law flavor. The prewar Constitution was based on the idea of legal positivism, originating from the late 19th-century German doctrine of state law and, therefore, gave no room for any concept deriving from the idea of natural law or higher law. Thus, the respect for individual rights contained in the postwar Constitution, along with the expansion of individualism in social and political development, are the most important features differentiating postwar and prewar Japanese society.

1. Enumeration of "Fundamental Human Rights." The Bill of Rights in the Constitution of Japan is more extensive than that of the American Constitution. First, the Constitution of Japan enumerates socioeconomic rights because of the influence of the Weimar Constitution and the experience of the American New Dealers. Second, the Constitution of Japan contains detailed safeguards in its provisions concerning the criminal justice process. In adopting the American system of criminal justice, which was unfamiliar to the Japanese, it was considered necessary to write detailed provisions. Third,

19. 1947 Const. art. 59(2)

20. Id. art. $60(2)$.

21. Id. art. $67(2)$

22. Until recently, because both houses had been controlled by the same party-the party in power, the Liberal Democratic Party ("LDP")-the difference in political posture between the two houses was rather small. In July 1989, however, at the latest regular election of members of the House of Councillors, the LDP lost its majority of seats for the first time in its forty-year history. The new stage for the development of the bicameral system may come in the future. 
freedoms are enumerated differently. Unlike the first amendment of the United States Constitution, which encompasses comprehensively diverse aspects of freedom, the Constitution of Japan provides for the protection of each freedom in separate articles: freedom of thought, ${ }^{23}$ freedom of religion (which stipulates the constitutional guarantee of the separation of state and religion), ${ }^{24}$ freedom of speech and of the press, ${ }^{25}$ freedom of gathering and association, ${ }^{26}$ and academic freedom. ${ }^{27}$

Socioeconomic rights, as typified by "the right to maintain the minimum standards of wholesome and cultured living," and more classic civil liberties, such as freedom of speech and of the press, are specified equally as "fundamental human rights." The Japanese public also tends to think that these rights are fundamental rights and should therefore be given the same level of protection. However, since we cannot and should not expect all the rights enumerated in the Constitution to be equally protected, some kind of differentiation among the various rights is necessary. Issues remain, however, as to what kind of theory and what sort of standard should be applied in determining the limits of judicial review, while giving deference to legislative discretion.

The "double standard" of scrutiny, which calls for strict scrutiny of alleged infringements of certain rights and more relaxed scrutiny of others, and which originated in Justice Stone's footnote four in United States v. Carolene Products Company, ${ }^{28}$ is widely, and, I must also add, roughly, accepted, not only by academics but also by the Japanese Supreme Court. ${ }^{29}$ However, there are more than a few who subscribe to the theory that, under the 1947 Constitution, which enumerates the socioeconomic rights as fundamental human rights, this standard should never be applied.

\section{Protection of Citizens' Rights}

a. Political freedom and other first amendment rights. It is generally accepted in Japan that the most important of our various "fundamental rights" are what Americans call "civil liberties." The role of the "consequentialist" reasoning is significant in emphasizing the nature of liberties as essential to democracy and the protection of liberties as a basic constitutional principle necessary for the democratic process. As a result, freedom of expression of political opinion by Japanese mass media is almost at the level of that of the Western democracies. There has been practically no legal limitation of the freedom of

\footnotetext{
23. 1947 Const. art. 19.

24. Id. art. 20.

25. Id. art. 21.

26. Id.

27. Id. art. 23.

28. 304 U.S. $144,152-53$ n.4 (1938)

29. The Supreme Court, in a Grand Bench decision, showed an affirmative position for adopting the "double standard" of judicial review akin to the U.S. practice. 26 Keishū 586 (Sup. Ct., G.B., Nov. 22, 1972).
} 
political opinion, except for the Subversive Activities Control Law of 1952. ${ }^{30}$ However, there have been just a few cases in which the application of this law became an issue. At the time this law was enacted, the Japan Communist Party ("JCP") or its front organizations, were its political targets, but no organization has ever been designated officially as a "subversive activities organization." No legal restriction has been imposed upon any political organization except for the JCP, which was outlawed by the Occupation powers for a short period. Streitbare Demokratie, or militant democracy, which justifies a deprivation of the political freedom of groups like the Communists under the name of "democracy," is not widely accepted among the Japanese people.

The status of the freedom of expression in Japan may be explained by the statement that "Japan is politically free, but socially not free." In the formal and legal political processes, political freedom is guaranteed to a remarkable extent. However, in the social processes that exist inside private corporations and organizations, freedom of expression has both heteronomous and autonomous restrictions that are based on a uniquely East Asiatic, or Japanese, sense of submission related to the Confucian concept of hierarchy. Still, the Japanese enjoy freedom of expression and keep a delicate balance between these formal and informal relations.

What kind of guarantee is given to the freedom of expression when it concerns moral judgments such as pornography? Generally speaking, an expression that is more remote from the political processes, and as a result closer to the "software" component of society, is more strictly regulated in Japan than in the West. The expressed justification for this tendency has a somewhat paternalistic character. ${ }^{31}$ In a time of active and extensive international exchange as we have today, such literature can easily be brought into Japan from abroad. Customs censorship is claimed to be an effective water's-edge operation to prevent the introduction of foreign immorality.

30. Law No. 240, 1952. This law was modelled after the United States Subversive Activities Control Act of 1950, 50 U.S.C. $\$ \S 781$ et seq. (1950). See infra note 89. As for the restraint on Communist movements, SCAP requested the Japanese Government to adopt a law regulating antiSCAP or anti-Government organizations. The Government followed SCAP's directive by enacting a Cabinet Order entitled "Order of Regulations on Organizations" (Cabinet Order No. 64, 1949) based on the United States Smith Act of 1940, 18 U.S.C. $\$ 2385$ (1988). This order prevailed during the Occupation. But with the termination of Occupation rule in April 1952, this law became ineffective because of the anomaly of its enactment procedures. In order to control civil liberties in a constitutional way, the Government should rely upon a law enacted by the Diet rather than by the Cabinet. At the time of ending the Occupation, SCAP and the Government were prepared for the enactment of a new law covering control of Communists: The result was the 1952 Subversive Activities Control Law. The new law came in force in July 1952, a few months after the end of the Occupation.

31. The leading case on obscenity control is the Supreme Court decision of 1957. The Court affirmed the constitutionality of government restraint on D.H. Lawrence's Lady Chatterley's Lover, Koyama v. Japan, 11 Keishū 997 (Sup. Ct., G.B., Mar. 13, 1957). Since then, the courts have made numerous decisions on obscenity issues. The general tendency of courts is to try to elaborate on the standard of obscenity, without, however, being bothered with arguments about the constitutional justification of government control of obscenity. As a result, a somewhat paternalistic and authoritarian reasoning enunciated by the Court's holding in 1957 is still regarded as controlling. 
When the constitutionality of customs censorship was challenged, the question was raised whether there was a violation of an explicit provision in the Constitution, which says "No censorship shall be maintained." 32 The Supreme Court gave less than convincing reasoning in ruling that "customs censorship" does not constitute "censorship."33

b. "Life, liberty and the pursuit of happiness." Article 13 of the Constitution of Japan, which states that "all of the people shall be respected as individuals," makes individualism a constitutional principle and a basic philosophy. This change is particularly significant in modern Japan. In prewar days, except in hypothetical terms, individualism was never a socially recognized ideology. The individual-completely contrary to Kant's categorical imperative-had been regarded as the ruler's tool. Article 13 goes on to provide that 'individuals' right to life, liberty and the pursuit of happiness shall, to the extent that it does not interfere with the public welfare, be the supreme consideration in legislation and in other governmental affairs." The right to life, liberty and the pursuit of happiness derives from the text of the Declaration of Independence of the United States.

It was only in the 1960s that the concept of privacy came to be commonly referred to in Japanese society. Since there is no Japanese equivalent for this word, the English word was adopted with Japanese pronunciation. The economic growth since the late 1960 s has enabled the Japanese to enjoy a certain amount of time for their personal lives. This change brought respect for privacy and autonomy in personal matters. The Supreme Court, in 1969, declared that Article 13 covers "freedom concerning private life." 34 The significant development of an information-oriented society in Japan has made clear the need to protect individuals' privacy. However, legal recourse for the protection of privacy is far behind that of the West, ${ }^{35}$ even though there seems to be no fundamental difference in the two areas' perceptions of the need for these protections.

Under the pressure of the Organization for Economic Cooperation and Development and other international organizations, the Japanese Government recently came to realize the desirability of protecting information about private matters and providing security for other data. They presented to the Diet a Cabinet bill concerning the protection of private information in an automated data system handled by administrative agencies. The bill passed the Diet in the end of 1988 and became effective in October 1989.36 Thus, finally Japan has achieved what is, more or less, an institutional

32. 1947 Const. art. $21(2)$.

33. Matsui v. Chief, Hakodate Customs Office, 38 Minshū 1308 (Sup. Ct., G.B., Dec. 12, 1984)

(a case on the constitutionality of the Customs Bureau censorship scheme).

34. Hasegawa v. Japan, 23 Keishū 1624 (Sup. Gt., G.B., Dec. 24, 1969).

35. Cf. A. Westin, Government Looks at Privacy and Security in Computer System 4 (1973) (summary of a Conference held at the National Bureau of Standards, Gaithersburg, Md., Nov. 19-20, 1973).

36. Law No. 95, 1988. 
protection scheme similar to that of the United States Privacy Act of 1974. ${ }^{37}$ It still remains to be seen whether this scheme will work very well.

c. Due process in criminal proceedings. In the field of criminal procedure, the Constitution of Japan, by providing fairly detailed provisions in several clauses, transplanted to Japan the American system of criminal justice, a system drastically different from the system then existing in Japan. Since the adversarial system had been utterly unknown in prewar Japan, in spite of the adoption of a completely new Constitution, the transplantation did not go smoothly at the working level.

One point that clearly distinguishes the Japanese Constitution from the United States Constitution is that the Japanese Constitution does not guarantee the right to trial by jury. The constitutional silence on this matter, and how this should be interpreted, is an interesting issue.

For a short period before and during the war (1928-1943), a type of strictly limited jury system was adopted. ${ }^{38}$ There is room for debate about the effectiveness and appropriateness of this system. In any case, the constitutional silence does not imply that trial by jury is prohibited, and there are advocates among lawyers who support its revival. Although many of those who support trial by jury believe that it is a system that prevents the courts from making mistakes, the validity of this argument remains questionable. A more convincing point raised by those in favor of trial by jury seems to be the democratic idea of the need to adopt a system that allows popular participation in criminal proceedings.

d. Equality under the law. An American lawyer once pointed out that, as compared to the United States, Japan has very few cases concerning Article 14, which guarantees equality under the law. ${ }^{39}$ In addition, none of these cases deals with the substance of the equal protection quarantees. There are fewer precedents concerning equal protection doctrine in Japan than in the United States. However, my personal opinion is that many of the issues dealt with by the fourteenth amendment of the United States Constitution are treated here in Japan under Article 14 as issues concerning socioeconomic rights.

37. The Privacy Act of 1974,5 U.S.C. § 552a (1988).

38. A 1928 Diet enactment introduced a jury system, Law No. 50, 1928. It was, however, suspended in 1943, Law No. 88, 1943. Since then, no action has been taken.

39. Article 14 provides:

All of the people are equal under the law and there shall be no discrimination in political, economic or social relations because of race, creed, sex, social status or family origin.

Peers and peerage shall not be recognized.

No privilege shall accompany any award of honor, decoration or any distinction, nor shall any such award be valid beyond the lifetime of the individual who now holds or hereafter may receive it.

1947 Const. art. 14. 
Generally speaking, Japanese are equality-minded rather than libertyminded, ${ }^{40}$ and the Japanese concern for equality is socioeconomic and substantive in nature. This observation does not mean that there is no issue of inequality in Japan. However, because the existing patterns of discrimination are not necessarily linked to legal sanctions, the problems are more difficult to solve.

The social characteristic of Japan, described earlier with the expression, "politically free, but socially not free," is also evident in patterns of discrimination. Discrimination against women and minorities-such as the people of a class called "Burakumin" 41 -remains deeply built into society, although it may not be reflected in the legal system. The mechanism of giving grants-in-aid to communities of people coming from the Burakumin class may be called a modified version of American affirmative action programs. ${ }^{42}$ Discrimination against women in labor relations is obvious; however, no affirmative action program has been adopted to remedy this situation. ${ }^{\mathbf{4 3}}$

The myth of the "homogeneous" Japanese prevails in Japan. Even former Prime Minister Nakasone, during his tenure of office, was proud of and boasted about "Japan's homogeneity."44 Through foreigners' eyes, this myth must appear xenophobic. Korean, Chinese, and Taiwanese residents in Japan, many of them born in Japan and having an appearance, behavior, and way of life almost indistinguishable from those of the Japanese, must find this myth particularly annoying. These "foreigners," like other foreigners, are also subject to various unwelcome special regulations. Whether or not such legal discrimination constitutes a violation of the Constitution is still a subject of debate. ${ }^{45}$

40. See Kato, Jivu to Matawa Byodo (Liberty and/or Equality), Sekai, Jan. 1985

41. Burakumin are descendants of persons classified as nonhuman, or not belonging to human society, during the Tokugawa period (approximately 1600 to 1868). Although all legal classifications of Burakumin were eliminated shortly after the Meiji restoration, social discrimination continues.

42. Law Concerning Special Financial Assistance for the Improvement of Designated Areas, Law No. 22, 1987

43. In accordance with the United Nations Convention on the Elimination of All Forms of Discrimination Against Women (adopted in 1977, effective 1985), an amendment law equalizing the working conditions of women was enacted. Law No. 45, 1985. The new law is, however, nothing more than a mere guidance program. It imposes upon employers only moral obligations of advancing women's positions and provides no legal sanctions for noncompliance.

44. On September 22, 1986, Prime Minister Nakasone spoke at a conference of the LDP on his favorite theory of the "racial singleness" of Japanese society. He maintained that the "intellectual level" of the Japanese people was higher than that of multiracial Americans. Criticisms on his statement came first from abroad rather than from within.

45. The most notorious shortcoming in Japan's human rights record is its treatment of aliens, particularly Koreans. See, e.g., Japan's Denationalization of the Korean Minority, 29 I.C.J. REV. 28 (1982); Report of the International Human Rights L.aw Group, Legal Treatment of Koreans in Japan (1986) (prepared by Yuji Iwasawa). 
IV

The Adoption of Foreign Law: Due Process AND Judicial Review

To understand the adoption of foreign law, we should consider how the concepts of due process and judicial review, transplanted to Japanese soil, have grown for forty years-what kind of branches and leaves have developed, how these features differ from the model, and why they differ. It is difficult work, indeed.

\section{A. The Concept of Due Process}

The process by which foreign law was incorporated into the Japanese Constitution can also be seen through the Constitution's treatment of the concept of due process of law. It is almost certain that the draftsmen of SCAP deliberately avoided using the term "due process of law" in the text of the Japanese Constitution. There is no due process clause identical to that which Americans have in the fifth and fourteenth amendments to their Constitution. Article 31 of the Japanese Constitution is similar to the due process clause. It says: "No person shall be deprived of life or liberty, nor shall any other criminal penalty be imposed, except according to procedure established by law." It was generally maintained in the early days of the Constitution that, however similar Article 13 might appear to be to its American cousin, it did not constitute a due process clause. The reasons were that, first, unlike the American model, Article 31 states, "No person shall be deprived of life or liberty" without mentioning "property." And, second, instead of the American phraseology, "without due process of law," Article 31 used the wording, "except according to procedure established by law." A majority of SCAP legal officers were New Dealers, and it is reasonable to assume that they hated the "substantive due process" analysis that invalidated much early New Deal legislation. Perhaps it is true that these Americans did not desire to introduce into postwar Japan the due process jurisprudence that had existed in the 1930s in the United States.

In connection with this topic, the Indian experience is illuminating. Article 22 of the Indian Constitution of 1949 provides: "No citizen shall be deprived of his personal liberty except according to procedure established by law." This Article was, as an Indian professor proves, written under the influence of Article 31 of the Japanese Constitution. ${ }^{46}$ It is reported that during the framing of the Indian Constitution, B.N. Rau, who was the constitutional advisor to the Constituent Assembly, visited North America for discussions with eminent persons in the field of constitutional law and was advised by Justice Felix Frankfurter not to include the due process clause in the Indian Constitution. Justice Frankfurter's position was “that the power of review implied in the 'due process' clause was not only undemocratic but also

46. Basu, Limitations of Fundamental Rights, 10 Kenpō Chosakai Shiryo 71 (1969) (with special reference to the Constitutions of the United States, India, and Japan). 
threw an unfair burden on the judiciary." 47 It seems that in order to get rid of the possibility of a judicial activist interpretation, the constitutional founders in both Japan and India took care not to introduce a due process clause.

The scope of the American concept of due process of law is wide, and it has various meanings. "Substantive due process" is not the only meaning of the due process clause. Above all, it connotes procedural safeguards in criminal proceedings. As discussed above, this aspect of due process is reasonably well covered by the Constitution of Japan in Articles 32 to 39. Thus, in contrast to the American concept, due process was institutionalized in the Constitution of Japan as a narrower concept, especially concerned with criminal justice.

The American concept of due process of law implies procedural safeguards not only in criminal proceedings, but also in every phase of the governmental process, including administrative proceedings. The Japanese, who had been influenced by German law, were utterly unfamiliar with the concept of procedural due process. Articles 32 to 39 enable the Japanese to enjoy due process protection within the field of criminal proceedings. But what about procedural due process in other areas of state power?

Twenty years ago-coincidentally twenty years after the promulgation of the Constitution of Japan-Professor Walter Gellhorn of Columbia Law School was asked at a session of the Cabinet Committee of Investigation of the Constitution to give his comments on the Constitution of Japan. He stated, "I have no hesitancy in expressing the belief that Japan has not yet sufficiently concerned itself with procedures." He continued, "I believe this [change regarding due process] to be one of the areas that most urgently deserves continuing study and reflection, lest the high aspirations of the Constitution be set at naught by crude methods of law administration." 48 He criticized the lack of respect for procedural safeguards in general, but his bitter comment was specifically concerned with the field of administrative process. There was no serious attempt to provide a citizen with procedural protections against an administrative agency. Such terms as the "right to notice" and the "right to have an opportunity for a hearing" were scarcely known to the Japanese at that time.

Many factors contribute to such an underdeveloped situation regarding procedural protection. The most important of all was the traditional lack of awareness on the part of the Japanese regarding procedural due process. If an explicit due process clause had been adopted, the new Constitution might have changed the way of thinking in this respect. But in actuality, the due process clause was deliberately excluded from the new Constitution. Though some institutions for due process were adopted in the area of criminal justice, their adoption was done in such a localized way that it was not enough to

47. B. Shiva Rao, The Framing of India's Constitution: A Study 235 (1968), quoted in Lester, The Overseas Trade in the American Bill of Rights, 88 Colum. L. Rev. 537, 544 (1988).

48. Gellhorn, Comment on the Constitution of Japan, 50 Kenpó Chosakai Shiryo 18 (1969). 
create a new sense of procedural due process with broader implications that might have been similar to American ideas.

Professor Gellhorn's observation was totally correct then, and still is so today to a great extent. However, a sign of an emerging Japanese sense of procedural due process was gradually shown in court decisions in the early 1960s. In 1962 the Supreme Court announced for the first time that in some situations Articles 29 and 31 of the Constitution required that "notice and opportunity of explanation and defense" be given to a person whose rights have been invaded. ${ }^{49}$ In 1963 the Tokyo District Court held for the first time that the court would reverse an administrative agency's denial of a license to become a taxi driver because the applicant had not been given notice and the opportunity for a hearing. ${ }^{50}$ A few months later, the same Tokyo District Court handed down a similar decision in the case of a bus route license. ${ }^{51}$ These two cases finally reached the Supreme Court, and in both cases the Court substantially affirmed the district court's position that the applicants should have been provided with notice and an opportunity to be heard. ${ }^{52}$ Interestingly, however, the Court held so as a matter of statutory interpretation, without mentioning constitutional law at all. Awareness regarding procedural due process has increased considerably, especially since the 1970s when the demand for participatory democracy increased.

As mentioned above, the adoption of "due process of law" in an explicit way was deliberately avoided by the draftsmen of the present Constitution. And, partly because of this lack of textual support, the development of the concept of "due process of law" was retarded and remained only in a narrow field. However, as modern constitutionalism and constitutional institutions, including the system of judicial review, have become more prevalent, the value of "due process of law" has been gradually recognized; we now can say that it has become part of our Constitution-without an explicit clause to guarantee that concept.

\section{B. The Concept of Judicial Review}

1. Arguments About Article 81. Article 81 of the Constitution of Japan provides that " $[t]$ he Supreme Court is the court of last resort with power to determine the constitutionality of any law, order, regulation or official act." Against the general background of American influence in the drafting and subsequent deliberations attending the enactment of the Japanese Constitution, it was reasonable to assume that Article 81 was intended to introduce the American system of judicial review developed from Marbury $v$.

49. The case concerned the confiscation of third-party property related to smuggling. 16 Keishū 1593 (Sup. Ct., G.B., Nov. 28, 1962).

50. 14 Gyōshū 1666 (Tokyo Dist. Ct., Sept. 18, 1963), aff'd, 25 Minshū 1037 (Sup. Ct., lst P.B., Oct. 28, 1971).

51. 14 Gyōshū 2255 (Tokyo Dist. Ct., Dec. 25, 1963), aff'd, 29 Minshū 662 (Sup. Ct., 2d P.B., May 29, 1975).

52. 25 Minshū 1037; 29 Minshū 662. 
Madison. ${ }^{53}$ This assumption finally prevailed, but not without some opposition. Some legal scholars took the position that Article 81 should be interpreted as conferring upon the Supreme Court a special power so that it would become a constitutional court as well as the highest court of appeal. ${ }^{54}$ Standing on the traditional legal viewpoint, they invoked Article 81. Under the prewar system, judicial review was utterly unthinkable; the Japanese could go only so far in accepting an institution such as a constitutional court or a constitutional review board of the European type. ${ }^{55}$ In 1948, however, in judging a criminal case, the Supreme Court declared: "Article 81 of our Constitution should be characterized as an explicit provision adopting the type of judicial review which has been established in the [United States] by way of the mere interpretation of the Constitution." 56 That statement was obiter dictum. The elaboration of this point remained for another occasion.

In October 1952, the Court elaborated on this issue in a case in which the chairman of the left-wing section of the Socialist Party was the plaintiff. ${ }^{57}$ The chairman filed suit against the state directly with the Supreme Court without first going through the screening of the lower courts. In his suit, the chairman asked the Court to declare that an ordinance establishing the Police Force Reserve, which was enacted only by the Cabinet, was in violation of Article 9, the pacifist clause, and was therefore invalid. The Supreme Court declined to review the merits of his arguments and instead held that litigation like this could not be sustained because there were only abstract arguments and no concrete case. The plaintiff had no standing to file an action. It is generally understood that, in so holding, the Supreme Court considered whether there existed a "case or controversy," which is required by the United States Constitution as a prerequisite to constitutional litigation. ${ }^{58}$

2. Transformation of Judicial Power. The purpose of the introduction of judicial review by Article 81 was to revolutionize the traditional concept of the judiciary. This change was not clearly recognized for a period after the Constitution's enactment, and, most likely, the revolutionary process remains unfinished even today.

53. 5 U.S. (1 Cranch) 137 (1803).

54. See, e.g., Sasaki, Saikosaibunsho no Kenpō Saibansho, 11 Kōнō Zasshi 1 (1950).

55. As early as 1914, one academic lawyer, Professor Sasaki of Kyoto University, influenced by the German and Australian idea of constitutional court (Verfassungsgerichtshof), argued that there was no constitutional obstacle to establishing such a body. Sasaki, Kenpō Saibansho no Gi, in RikkeN Hirriken, Kobundo 330 (1917).

56. Komatsu v. Japan, 2 Keishū 801, 806 (Sup. Ct., G.B., July 8, 1948).

57. 6 Minshū 783 (Sup. Ct., G.B., Oct. 8, 1952).

58. Another question concerning the interpretation of Article 81 was whether the lower courts were also entitled to review the constitutionality of legislation. If put to an American, an affirmative answer would come back almost automatically. By contrast, through Western European eyes, the text of Article 81 looks as if only the Supreme Court was granted special power to review the constitutionality of state actions. In 1950, the Court decided in favor of the lower courts. This is another indication of the adoption of the American model. Yanagi v. Japan, 4 Keishū 73 (Sup. Ct., G.B., Feb. 1, 1950). 
According to the prewar concept of judicial power, based on German constitutional doctrine, judicial courts were used only for solving legal disputes among citizens and for dealing with criminal sanctions. All other litigation was outside the jurisdiction of judicial courts. Thus, for example, administrative law litigation could be handled only by a special tribunal within the administrative branch. ${ }^{59}$ It would seem that this concept of the judiciary was closely related to the peculiarly German idea of the dualism of state and society. Judicial courts should be concerned with matters within society, and the government (or the crown) should be responsible for state affairs involving matters of the relationship between the state and society.

Article 81 of the new Constitution provides judicial courts with the power to review an act's constitutionality, a concept that had been absolutely foreign to the traditional concept of the judiciary. Furthermore, it is almost an established interpretation that under Article 76, clauses 1 and 2, no administrative court, as existed in prewar Japan, shall be maintained. Against the backdrop of these two constitutional provisions and of the general character of the whole Constitution, it seemed rather natural to assume that the framers were creating a brand-new concept of judicial power. But the process of its creation has not proven to be an easy one.

In 1953, the Japan Association of Public Law published issue number 8 of Köho Kenkyu. ${ }^{60}$ The journal is divided into three parts, one of which is entitled, [The] Relationship Between the Administrative Power and the Judicial Power. The leading article is entitled Prerogatives of Administrative Authorities Against Judicial Review and was written by Professor Joji Tagami of Hitotsubashi University. Professor Tagami emphasized the limitations on judicial power in relation to administrative activities. He seemed particularly interested in narrowing judicial judgments based on the merit of administrative decisions by stressing the discretionary power of administrative agencies. He also argued that both declaratory judgments and mandamus writs were generally impermissible against administrative authorities.

An article by Professor Yoshimoto Yanase appears in the same journal section. ${ }^{61}$ Professor Yanase firmly adhered to the traditional, narrow concept of judicial power in spite of the constitutional change. ${ }^{62}$ Professor Yanase maintained that the jurisdiction of the judiciary covered only civil and criminal litigation and that, therefore, disputes concerning administrative law belonged intrinsically to an area outside (fremdes gebiet) of the judicial power. Further, he insisted that there was an essential limit on judicial intervention in the field of administrative law. The reader will notice in the articles appearing in Köhó Kenkyu the frequent repetition of terms such as

59. See MeIjI Const. art. 61.

60. Tagami, Prerogatives of Administrative Authorities against Judicial Review, 8 KōHō Kenkyu 100-11 (1953).

61. Yanase, [The/ Relationship Between the Administrative Power and the Judicial Power, 8 KōHô KeNKYU 123-29 (1953).

62. Professor Yanase's mentor, Professor Tatsukichi Minobe, took the same position in this respect. Minobe, Nikonkoku Kenpó Genron, in YaнikakU 449, 454 (1947). 
"independence of administrative authorities from the judiciary" and "supremacy of the administrative power."

The articles and essays contained in the journal were representative of the then-prevailing concept of judicial power. About that time I graduated from law school and started my apprenticeship to an academic career. I remember that while reading these articles and essays I felt much irritation. But I must confess that I did not know how to overcome it; they looked so confident. This was the doctrinal situation that confronted the new concept of the judiciary.

The doctrinal atmosphere surrounding the concept of judicial power in relation to administrative authorities has changed slowly since then. Now, no scholar seems to stick to the traditional narrow concept, and judicial power is interpreted as extending to suits against administrative agencies as well as to civil and criminal proceedings. Judicial control over administrative discretion has thus greatly expanded, and such expressions as "independence of administrative authorities from the judiciary" and "supremacy of the administrative power (over the judiciary)" are rarely heard.

It appears, however, that elements of the traditional, limited concept of judicial power remain and control both the judiciary's way of thinking and way of operation. One of the most conspicuous indications is the insufficiency of judicial remedies against administrative authorities. First, the Administrative Litigation Law strictly limits the opportunity to issue preventive injunctions against administrative decisions and makes explicitly impermissible provisional dispositions of any administrative actions. ${ }^{63}$ Second, there are no provisions for declaratory judgments or mandamus. ${ }^{64}$ For these reasons, the prevailing opinion is that judicial courts can neither make declaratory judgments nor issue writs of mandamus against administrative bodies. These limitations on judicial remedies provoke various arguments about administrative law proceedings at large. Needless to say, however, in the case of constitutional litigation, these limitations are more problematic, since the infringement of a citizen's fundamental right is involved more frequently than in other cases.

Let us look, for instance, at a case concerning the constitutionality of the apportionment of seats for the House of Representatives. In 1976, the Supreme Court declared for the first time that the seat allocation for the House of Representatives provided in the Public Officials Election Act violated the constitutional guarantee of equality under the law. ${ }^{65}$ The Supreme Court first took the opportunity to consider an apportionment

63. Law No. 139, 1962, arts. 25, 44.

64. There is a single example of permissibility in Article 146 of the Local Government Law of 1947. Mandamus proceedings provided for under that law are regarded as strictly exceptional ones, constituting controlling powers of the central government over local governments.

65. Kurokawa v. Chiba Prefecture Election Comm'n, 30 Minshū 223 (Sup. Ct., G.B., Apr. 14, 1976) (interpreting the Public Officials Election Act, Law No. 100, 1950, as amended by Law No. 132,1964 ). 
controversy in 1964, in a case concerning the House of Councillors. ${ }^{66}$ In this case, the issue was more delicate than in the later House of Representatives' case since, in the former, the controversy revolved around the particular issue of how to consider prefectures as constituency units. The Supreme Court made a great deal of the Diet's ability to frame constituency units, and, emphasizing the broad extent of legislative discretion, upheld the constitutionality of the law under attack. Thus, the Court relied upon the legislature's wide discretion, not upon the American political question doctrine. By contrast, in his separate supplemental opinion, Justice Saito Kitaro argued that the case was nonjusticiable, adopting arguments similar to those in Justice Frankfurter's 1962 dissenting opinion in Baker v. Carr. ${ }^{67}$

No immediate remedy in the plaintiff's favor was expected from the Court's holding the disputed law unconstitutional. This was not necessarily due to the Supreme Court, but primarily due to what I would submit is the defective system of constitutional litigation.

In accordance with Article 204 of the Public Officials Election Act, which enables any voter to file a suit to invalidate a recent election, the plaintiff instituted this suit against the Chairman of the Chiba Election Supervision Commission. There is no doubt that the original intention of Article 204 was to make it possible for the voters to ask that an election of specific candidates be nullified for technical reasons. With regard to malapportionment suits, a specific case is not necessarily concerned with the particular candidate's fate but rather with the whole system of seat allocation. Moreover, plaintiffs in malapportionment cases do not always request to invalidate the particular election already held, but seek to make it impossible to apply the current seat allocation law to any future elections. For the purpose of malapportionment disputes, the most appropriate remedies are declaratory judgments, preventive injunctive relief, or both. However, there is no law that supports the permissibility of such judicial remedies in Japan.

I believe that, irrespective of the lack of legislative support, the courts may create a remedy that will prevent the invasion of a citizen's constitutional right. But the prevailing opinion of administrative law takes the position that neither declaratory judgments nor preventive injunctions are within the realm of judicial power. It is unlikely that in the near future the courts will invent a remedy so that plaintiffs may question the validity of a seat allocation law before an election has actually taken place.

Thus, at present, Article 204 is regarded as the only route available for plaintiffs in malapportionment litigation. Article 204 litigation is concerned with the validity of an election already completed. It is almost impossible for the Supreme Court to nullify a nationwide election as a whole, because the invalidation of the election may invalidate all of the important political

66. Koshiyama v. Chairman, Tokyo Metropolitan Election Comm'n, 18 Minshū 270 (Sup. Ct., G.B., Feb. 5, 1964). For an English translation of the case, see H. ITOH \& L. BeER, ThE Constitutional Case Law of Japan 53-57 (1978).

67. 369 U.S. 186, 266 (1962) (Frankfurter, J., dissenting). 
decisions made by the Diet, such as the appointment of the Prime Minister, legislative or budget matters, and treaty enactments. Therefore, as the Supreme Court showed in its 1976 holding, it is practically forced to avoid invalidation of an election, despite its judgment of the unconstitutionality of a law under attack. The political status quo is almost always strong enough to nullify whatever action the Court may want to take. Not only because of Japanese adherence to the narrow concept of the judicial power in relation to state powers, but also perhaps because of the lack of equitable institutions, no attempt has been made to renovate the system of remedies for constitutional litigation. It is now time to do so.

3. A General View of Judicial Review in Operation. During the past forty years, there have been five occasions on which the Supreme Court denied the validity of legislation on constitutional grounds. 68 Opinions will vary as to whether the figure, five, constitutes a good or bad record as an indicator of the function of our judicial review system. We can surely say, however, that against the countless number of enactments during the same period, the figure five is undoubtedly small. Is it the excellent nature of draftsmanship that prevents the Diet from making bad laws? Or, rather, is it the negativist, or self-restraining, approach of the Supreme Court that makes the Court apt to respect legislative determinations? It would not be unfair to say that most scholars and lawyers share the opinion that negativism in judicial review is one of the most characteristic features of the Japanese Supreme Court. Throughout the forty-year history of the Constitution, the expression "wide legislative discretion" has been employed by the courts in one way or another. Even in the field of freedom of expression, the Supreme Court is willing to speak about "legislative discretion." 69

68. Article 200 of the Penal Code, which imposes heavier penalties for committing patricide than for regular homicide, was held unconstitutional as violating the equal protection clause, Article 14, clause 1, of the Constitution. Aizawa v. Japan, 27 Keishü 265 (Sup. Ct., G.B., Apr. 7, 1973) (affirming 1 Keisai Geppō 544 (Utsunnomiya Dist. Ct., May 19, 1969) and reversing 619 Hanrei Jihō 93 (Tokyo H. Ct., May 12, 1970)). A law regulating the location of drugstores was held unconstitutional as against the constitutional protection of free enterprise, Article 22 of the Constitution. Umehara v. Japan (The Pharmacy Case), 29 Minshū 572 (Sup. Ct., G.B., Apr. 30, 1975). In Kurokawa, the Court found the law to be unconstitutional on the basis of the equal protection clause but did not invalidate the challenged law. 30 Minshū 223. See also Kamao v. Hiroshima Election Comm'n, 39 Minshū 1100 (Sup. Ct., G.B., July 17, 1985). The Forest Law, which restrained a certain type of claim for the division of common ownership of forestry, was held unconstitutional because it violated the guarantee of property rights, Article 29, clause 1. Hiraguchi v. Hiraguchi, 41 Minshū 408 (Sup. Ct., G.B., Apr. 22, 1987).

69. The Public Officials Election Act absolutely prohibits door-to-door election canvassing. Since 1950 the Supreme Court has continuously held that such regulation is constitutional. 4 Keishū 1799 (Sup. Ct., G.B., Sept. 27, 1950); 21 Keishū 1245 (Sup. Ct., 3d P.B., Nov. 21, 1967) (translated into English in H. Itoh \& L. BeER, supra note 66, at 149-51. See generally L. Beer, Freedom of EXPRESSION IN JAPAN 376-77 (1984). In the beginning, the Supreme Court relied on the broad "public welfare" standard. Now, however, the Court prefers to give weight to the wide discretionary powers of the legislature. Typical examples are seen in Justice ltoh's opinions: 38 Keishū 387 (Sup. Ct., 3d P.B., Feb. 21, 1984); 35 Keishū 568 (Sup. Ct., 3d P.B., July 21, 1981). The prevailing understanding in Japan, that the state has a free hand to regulate election canvassing, greatly contrasts with the American perception that free canvassing should be guaranteed to the greatest degree possible, especially for election purposes. I am of the opinion that the state should not have 
Perhaps it should be noted here that the Supreme Court has never held unconstitutional any regulation on freedom of expression. The Court once suggested that freedom of expression deserves more protection than freedom of economic activities and that, therefore, court examinations should be more strict in the field of free expression. ${ }^{70}$ In practice, however, the Court has never strictly scrutinized regulations on free expression. Considering that the Court has twice declared economic regulations unconstitutional, it appears that the Court treats freedom of economic activities more seriously than freedom of expression.

It seems that there is a general tendency for the Supreme Court to avoid constitutional judgments as much as possible. In contrast, the United States Supreme Court has observed Justice Brandeis' admonition calling for judicial self-restraint, but has found laws unconstitutional when necessary. ${ }^{71}$

As discussed previously, in 1971 the Supreme Court affirmed the decision of the lower court concerning an application for a taxi driver's license, saying that the administrative agency had denied the application for the license without first providing the applicant with proper notice and an opportunity for hearings. ${ }^{72}$ For the first time, the Supreme Court was speaking about a citizen's right to procedural due process in an administrative proceeding. While the Tokyo High Court as well as the Tokyo District Court based a citizen's right on Articles 13 and/or 31 of the Constitution itself, the Supreme Court did not rely upon any constitutional provisions. The Court established the right as if it existed as a necessary result of the interpretation of the Road Transportation Law. ${ }^{73}$

To the Court, this was not constitutional litigation but a regular case of administrative law. However, it should be noted that the reason the agency denied the application without complying with the procedural requirements was that there was no explicit provision in the law conferring upon an applicant the right to notice and the opportunity for a hearing. Therefore, it is fair to say that the Court invented a new interpretation of the law so that, for the first time, applicants were able to enjoy procedural safeguards with respect to administrative agencies. It is almost certain that in so doing the Supreme Court was guided by the liberal, democratic spirit of the Constitution. Without relying on the Constitution, it would have been impossible for the Court to have invented such a right.

Why, then, did the Court not mention anything of a constitutional nature? The reason seems rather simple: If the Court had relied upon constitutional law, the coverage of a citizen's right to notice and opportunity for a hearing would extend to various administrative processes other than the one

wide discretionary powers to regulate election campaigns. See, for example, Y. Okudaira, Naze HYOGENNo JiYuKa 153-220 (1988), in which I analyze Japanese case law and make some comparative observations by referring to American cases.

70. 26 Keishū 586.

71. See, e.g., Ashwander v. TVA, 297 U.S. 288, 346-48 (1936) (Brandeis, J., concurring).

72. 25 Minshū 1037.

73. Law No. 183, 1951, arts. 6, 122. 
concerned in the instant case. On the other hand, if confined by the narrow framework of statutory interpretation, the recognized right is only applicable to cases within the same framework. By failing to acknowledge constitutional questions, the Japanese Supreme Court seems to want to decide constitutional issues on a case-by-case basis.

Another example indicating the same tendency to operate on a case-bycase basis is contained in one of the Court's most recent decisions. The case concerned the lawfulness of a judge's order prohibiting those in attendance from taking notes during courtroom proceedings. Theoretically, this kind of restraint order is made on the basis of the discretionary, disciplinary powers of the individual judge presiding over the court; in practice, however, almost all trial courts have adopted a similar rule of general prohibition. A few years ago, an American lawyer filed a suit against this type of prohibition. The Tokyo District Court dismissed the action and held that the prohibition order was within the discretionary powers of the presiding judge, and that there was nothing unlawful about such an order. ${ }^{74}$ This holding was affirmed by the Tokyo High Court. ${ }^{75}$ The plaintiff appealed to the Supreme Court. Surprisingly, the Supreme Court reversed the judgment of the lower court in substance and declared that, in spite of a judge's wide disciplinary powers, the presiding judge was not allowed to prohibit those in attendance from taking notes, irrespective of the type of case. ${ }^{76}$

It seems that the issue presented was related to a citizen's right to attend, inspect, and record court proceedings, and as such it was very much similar to the issue that the United States Supreme Court confronted in Richmond Newspapers, Inc. $v$. Virginia 77 and similar cases. In those cases, the United States Supreme Court dealt, without the slightest hesitation, with the issue at the constitutional level as a problem regarding first amendment rights. In contrast, however, the Japanese Supreme Court solved the case simply on the basis of the scope of a judge's discretionary and disciplinary powers. Evidently our Court would not like to make any affirmative statements about the people's right to know, because, once open to that direction, constitutional claims would extend from the right to take notes in the courtroom to the right to inspect various government institutions, as well as to the right to have access to government records. ${ }^{78}$

One additional example is helpful. The top leader of one of Japan's largest and most influential religious organizations charged a magazine publisher with the crime of defamation and claimed that his reputation had

74. Repeta v. Japan, 1222 Hanrei Jihō 28 (Tokyo Dist. Ct., Feb. 12, 1987). The case is known as the "Repeta" case following the name of the American plaintiff.

75. 1262 Hanrei Jihó 30 (Tokyo H. Ct., Dec. 25, 1987).

76. 43 Minshū 89 (Sup. Cı., G.B., Mar. 8, 1989).

77. 448 U.S. 555 (1980). See also Press-Enterprise Co. v. Superior Court of California, 464 U.S. 501 (1984); Globe Newspaper Co. v. Superior Court for the County of Norfolk, 457 U.S. 596 (1982).

78. In Japan, there is no "open government" legislation such as the American Freedom of Information Act, 5 U.S.C. $\$ 552$ (1988), the Federal Advisory Committee Act, 5 U.S.C. app. $\$ 1$ (1988), and the Government in the Sunshine Act, Pub. L. No. 94-409, 90 Stat. 1241 (codified as amended in scattered sections of 5 U.S.C. \& 39 U.S.C.). 
seriously been harmed by the defendant's publication. The publisher was indicted. ${ }^{79}$ The issue presented was precisely the freedom of expression versus a person's right to enjoy his reputation. The questions asked were whether the publisher's constitutional right was more important than the leader's personal claim and, if so, why and to what extent? Borrowing the American terminology, the Court was dealing with the concept of a "public figure." Needless to say, in the United States, that concept belongs within the area of constitutional law. The first amendment is the starting point: The concept of "public figure" has been created and clarified by the courts in order to uphold the first amendment and to accommodate other interests such as personal reputation or privacy.

The same must apply to Japanese jurisprudence when dealing with the concept of "public figure." In contrast, however, in the defamation case of the religious leader mentioned above, the Supreme Court spoke little about constitutional law or the guarantee of freedom of the press. The Court solved the case almost exclusively within the framework of statutory interpretation. The resolution of the case was correct-I have no serious objection with it. What is annoying is the way the Court resolved the issue.

The Court introduced a kind of "public figure" concept by setting three requirements to establish defamation. ${ }^{80}$ The Court did this by merely interpreting the defamation law. A young American lawyer, a postgraduate student who was studying in Japan, remarked "I have recently examined the Supreme Court decision carefully. But one thing puzzles me very much. The Court does not say much about the Constitution. It talks only about statutory construction. Is statutory law predominant over the Constitution in Japan?" It is not clear why the Supreme Court preferred to rely on statutory

79. Prosecution of defamation is instituted only upon a charge from the injured person. PENAL Code art. 232, Law No. 45, 1907. The substantive law of criminal defamation appears both in Articles 230 and $230(2)$ of the Code. Article 230 provides:

1. A person who defames another by publicly alleging facts shall, regardless of whether such facts are true or false, be punished with imprisonment at or without forced labor for not more than three years or a fine of not more than 1,000 yen.

2. A person who defames a dead person shall not be punished unless such defamation is based on a falsehood.

Article 230(2), which was inserted into the Penal Code in 1947, Law No. 124, 1947, originated from Article 45 of the Newspaper Law, Law No. 41, 1909. Right after the war in 1945, the Newspaper Law was first suspended and then finally abolished. Law No. 95, 1949. Article 45 of the Newspaper Law was, as it were, transplanted, with minor modification, into the Criminal Code. It says:

1. When the act provided for in paragraph 1 of the preceding article is found to relate to matters of public interest and to have been done solely for the benefit of the public and, upon inquiry into the truth or falsity of the alleged facts, the truth is proved, punishment shall not be imposed.

2. In the application of the provision of the preceding paragraph, matters concerning the criminal act of a person for which prosecution has not yet been instituted shall be deemed to be matters of public interest.

3. When the act provided for in paragraph 1 of the preceding article is done with respect to matters concerning a public servant or a candidate for elective public office and, upon inquiry into the truth or falsity of the alleged facts, the truth is proved, punishment shall not be imposed.

Law No. 41, 1909 (repealed, Law No. 95, 1949).

80. See Penal. Code art. 230(2); discussion supra note 79. 
construction rather than on Article 21 of the Constitution. However, one thing is certain: If you are successful in establishing such a doctrine on constitutional grounds rather than on a mere statutory basis, the position of the doctrine will be stronger because it would be invulnerable to any change in the law concerned.

4. Origins of Judicial Negativism. It is difficult to explain judicial negativism in Japan in a systematic way. However, we might make a tentative observation. The Supreme Court functions as the highest court not only of constitutional law, but of all types of law. Such characteristics of the Court as a "regular court" can be found in the United States model. ${ }^{81}$ However, since the United States has a federal system, the jurisdiction of the Supreme Court as a federal institution is limited. Within such jurisdiction, the category of constitutional litigation is likely to be distinguished from other "regular" litigation. On the contrary, Japan has a unitary system and therefore the Supreme Court handles diverse cases including even legal conflicts relating to the bylaws of local government. Justices are expected to manage legal technicalities and to develop neat interpretations of law. Such justices are assisted by Supreme Court Investigation Officers who are career judges, well versed in the technicalities and the arts of interpretation. Thus, most justices are inclined to follow the thinking pattern of career judges, or at least those justices with backgrounds as career judges are likely to hold the leadership among the justices. It is natural for them to become more apolitical or conservative. Justices of the Supreme Court are appointed by the Cabinet ${ }^{82}$ and, except for the immediate postwar period, Japan has been ruled by a single, conservative party, the LDP. This means that the power to appoint Supreme Court justices has been monopolized by this conservative political party. It is, in a sense, natural for the Cabinet to appoint pro-LDP legal experts who have conservative attitudes. The Cabinet, as a rule, considers candidates from among career judges, prosecutors, practicing lawyers, and law school professors, on the basis of the recommendations of some sections of the legal community. With few exceptions, only men beyond the age of sixty-two or sixty-three have been selected, and no woman has ever been suggested as a candidate. The retirement age of justices is seventy years. ${ }^{83}$ In the fall of 1989 , two justices retired from the bench and two new justices replaced them. During 1990, six more justices will retire. Thus, in less than one and a half years, more than one-half (eight out of fifteen) of the justices will be replaced-a drastic change in personnel. However, given the realities of how

81. So far as the characteristic of the Supreme Court as a "regular court" is concerned, I submit that our Court resembles the High Court of the Commonwealth of Australia. See Okudaira, The Australian and Japanese Constitutions, in JaPan And Australia 169, 181-82 (P. Drysdale \& H. Kitaoji eds. 1981).

82. 1947 Const. art. 79. As to the Chief Justice, Article 6, clause 2 provides that " $[t]$ he Emperor shall appoint the Chief Judge of the Supreme Court as designated by the Cabinet." The tennō's appointment of the Chief Justice is just nominal. The Cabinet designation is everything in this matter.

83. The Judiciary Law, Law No. 59, 1947, art. 50. 
justices are appointed, it is rather difficult to expect such a group of people to challenge the status quo.

The foregoing discussion does not necessarily mean to suggest that the party in power selects justices simply on the basis of political beliefs. As a matter of fact, the LDP or the Cabinet has employed a sort of quota system by which a fixed number of justices' seats are allocated to a few different circles of the legal profession. Five or six seats are for candidates from the circle of career judges. The career judges chosen are most likely those who have been either a chief judge or otherwise a senior judge of a high court. The most certain way to be promoted to justice on the Supreme Court is to have first occupied the position of secretary general of the Supreme Court. ${ }^{84}$ From the circle of public prosecutors, three or four persons are selected from among those who work for the Supreme Public Prosecutor's Office or serve as the head of a High Public Prosecutor's Office. Interestingly, one seat has customarily been reserved for a career diplomat.

Although this description of the selection process for justices is incomplete, it is enough to understand that the Court consists of people who serve as a sort of representative from each circle of the profession and that, as such, the Court constitutes an institution of stratification. It is no wonder then that in this highly bureaucratic machinery, formalism controls, and respect for the status quo is of primary importance.

It is an undeniable fact that the type of judicial review developed by the United States Supreme Court is unique. The Court, which against the background of the rule of law or the British tradition of judicial supremacy had established itself as a firm institution, came to gain new powers and prestige in extending judicial protection against the curtailment of civil liberties during and after World War I and in fostering the new system of federalism to develop welfare policies since the New Deal era. In Japan, on the other hand, there has been no tradition of judicial supremacy and no history of Supreme Court achievements. In spite of such a clear clause as Article 81 of the Japanese Constitution, it might be unwarranted to expect Japan's Supreme Court to be as powerful and prestigious as its American counterpart.

In any event, anyone must admit that the prestige of the Japanese Supreme Court is not as high as that of its United States counterpart. The Court has never played the unique role in the country's political and social life that the United States Supreme Court has played. The Court has never been the subject of bitter criticism or high praise from the outside world, and it seems the justices are quite satisfied with their situation. Perhaps our Court knows it has neither enough authority nor enough prestige to hand down

84. See, e.g., Danelski, The Political Impact of the Japanese Supreme Court, 49 Notre Dame L. Rev. 955, 979 (1974). Three consecutive chief justices-Terada Jiro (1982-85), Yaguchi Koichi (1985-90) and Kasaba Ryohachi (1990- )-share the same experience of having served as Secretary General of the Supreme Court before their appointments as justices. 
decisions such as INS v. Chadha ${ }^{85}$ or Texas $v$. Johnson, ${ }^{86}$ which strike hard blows either at the Congress or at the administration, or at both. Because the Court does not venture to challenge another branch of the government, its authority is not augmented and its prestige does not increase. It looks as if it is caught in a vicious circle.

\section{V}

\section{Extrajudicial Factors Supporting Human Rights in Japan}

I am inclined to undervalue the role our Supreme Court has actually played in creating a new constitutional order and in protecting citizens' constitutional rights. Do all the rights and liberties happily enumerated in the Constitution remain unprotected? Should we still consider Japanese society to be as unliberal and undemocratic as it was before the war? The answer to these questions is no.

Generally, the degree of protection of civil liberties and other fundamental human rights in Japan is not insignificant compared to that of Western countries. In particular, political freedom is greatly safeguarded and subjected to almost no direct restraint by the government. There is no legal impediment to criticism of the government, politicians, and bureaucrats. Japan is not free from problems in this field of law. On the contrary, in our own way we are confronted with plenty of problems. However, I believe that every country, each with its own unique social circumstances, also has its own weaknesses in the area of protecting civil liberties and citizens' rights. Japan is no exception.

In short, it is not unfair to say that the Japanese people enjoy a good level of civil liberties and civil rights. Why did that become possible in such a constitutionally underdeveloped society in which the courts-the formal institutions-are not very enthusiastic about protecting citizens' liberties and rights? The first condition I would like to point out as advantageous to the establishment of people's rights and liberties is the economic factor. During these forty years or so, Japan has witnessed the successful development of its economy, which in turn has contributed to a rather smooth process of making the society stable and modern. Economic growth in Japan has never been in conflict with the development of individual rights, but, rather, by fostering the development of independent citizens and the modernization of labormanagement relations, the protection of these rights has contributed to economic growth. ${ }^{87}$

One of the most important factors encouraging Japanese economic growth and the protection of citizens' rights is the favorable effect of the international

85. 462 U.S. 919 (1983).

86. 109 S. Ct. 2533 (1989).

87. Akio Morita, Chairman of Sony Corporation, emphasizes the impact of the constitutional guarantees of citizens' rights not only on the development of his own company, but also on the economic growth of Japan. A. Morita, MADE IN JAPAN 151-56, 171-72, 201 (1986) (Japanese language version). 
circumstances which surround Japan. Unlike many other countries in Asia's recent history, Japan has not been involved in international conflicts. If Japan were a divided nation like South and North Korea, its citizens would have felt the tension caused by the division; as a result, the curtailment of civil liberties would have been regarded as inevitable. The fact that Japan is a lucky country in terms of its current international circumstances constitutes, I submit, the second element that is advantageous to the protection of citizens' rights.

Third, I would like to point out the particular effect of the legal reforms carried out during the Occupation. Prewar Japan was notorious for governmental restraints on civil liberties. There were a great number of suppressive laws conferring wide powers on the police. The Occupation powers urged the Japanese Government to eradicate those laws at their roots. With some minor exceptions, the clearance of those "bad laws" was accomplished. ${ }^{88}$ Japan started its postwar modernization from scratch, free from various suppressive laws. It is difficult to resurrect anything once it is abolished. This particularly applies in the case of the repealed "bad laws."

Since Japan became independent in 1952, some conservative, nationalistminded politicians have tried to reintroduce several suppressive laws of the prewar type, but almost always in vain. 89 With all the powers that the LDP possesses, it is not inclined to introduce and carry forth confrontational bills that are likely to provoke controversies among the people. Bills imposing limitations on civil liberties are certainly confrontational ones. This means

88. We cannot, however, neglect the fact that SCAP requested the Japanese Government to make special enactments for the interest of the Occupation powers, some of which were as suppressive as the police laws of prewar Japan. See, e.g., Imperial Order No. 311, 1946; Cabinet Order No. 201, 1948; Cabinet Order No. 64, 1949. SCAP's Directive in June 1950 to prohibit the publication of Akahata, the Communist Party's organ, and Cabinet Order 325, 1950, were also examples of this kind of legislation. It was almost an established doctrine that these orders issued by SCAP's directives were beyond the effect of the Constitution because SCAP itself was superconstitutional. There was no court decision during the Occupation in which the validity of legislation of this type was examined.

89. Perhaps the Subversive Activities Control Law, Law No. 240, 1952, was an exception. See supra note 30 . Overcoming strong opposition movements, this law was enacted pursuant to a special Cabinet Ordinance made under SCAP's directive. The Subversive Activities Control Law confers upon the Director of the Public Safety Investigation Bureau the power to request, after the Bureau's investigations, the Review Commission of Public Safety to regulate certain activities of any organizations that are deemed to be engaged in overthrowing the Government by violence. The sanctions imposed upon such organizations by the Review Commission are varied, yet all are strictsimilar to the sanctions of the United States counterpart, 50 U.S.C. $\$ \$ 781$ et seq. However, since its enactment in 1952, there has been no case in Japan in which the Director of the Investigation Bureau requested the Review Commission to regulate any organizations, including the Communist party and its affiliated groups. We have several criminal cases where there was an attempt to apply Article 38 of the law, an anti-incitement clause, to radical speakers or bill distributors. But these were not concerned with regulation of organization. If the actual legislative purpose of the Subversive Activities Control Law is control on organizations' subversive activities, there has been no attempt in Japan to invoke that law as originally intended. Except for a short period during the Occupation, the Communist Party has never been troubled by governmental restraints, and has continuously had a meaningful number of its representatives elected to the Diet. In the late 1940 s and early 1950 s, antiCommunist sentiment was somewhat provoked when Prime Minister Shigeru Yoshida suggested the introduction in either the Cabinet or in the Diet of an Un-Japanese Activities Committee modelled after the Un-American Activities Committee. In Japan, however, "McCarthyism" never became as strong as it was in the United States. 
that the LDP realizes that the people have become sensitive to restraints on civil liberties-sensitive enough to react strongly against any attempt at such legislation. This sensitivity of the people, or the people's consciousness regarding fundamental human rights, is really one of the characteristics that distinguishes our contemporaries from the people of prewar Japan. This sensitivity is the fourth factor that is advantageous to the protection of citizens' rights.

For better or worse, the Japanese are so fond of the term "human rights" that foreigners are amazed at how frequently the Japanese use this term. The term, of course, originates from the fundamental human rights mentioned in the Constitution. Whether conscious of the constitutional connotation, the Japanese are apt to use the term human rights even at times when such words as "right," "claim," or "entitlement" would be more appropriate for the particular context. They say, for example, "human rights of women," "human rights of children," "foreigners' human rights," and even "human rights of taxpayers." The term seems to imply an emotional attraction to which the Japanese are susceptible.

Illustrative of this devotion to human rights are the disputes over the Foreigners' Registration Law, which requires every foreigner over the age of sixteen who is staying in the country for more than one year to have his or her fingerprints taken. ${ }^{90}$ Until recently, there had been a provision in that law which required that the fingerprints be taken again every five years thereafter. ${ }^{91}$ According to the original law of 1952, foreigners over the age of fourteen, rather than sixteen, were requested to have their fingerprints taken, and they had to repeat this procedure every two years rather than every five years. The history of the amendment of this law is a bit complicated and is traceable to the change of immigration policies at large as well as policies regarding Korean and Chinese permanent residents in Japan. I believe that the law was copied after the United States Foreigners' Registration Act, which was a product of a national emergency. ${ }^{92}$ While the fingerprint requirement is not used in the United States any longer, Japanese immigration authorities are too serious about their duties to stop enforcing the law. Moreover, there are a great number of Korean residents in Japan whose nationality is either of the Republic of Korea or of the Democratic People's Republic of Korea, and as such are treated as foreigners. ${ }^{93}$

Most Korean residents adopt a Japanese way of life, particularly after two or three generations. However, all of them must appear before the immigration authorities every five years and have their fingerprints retaken. A few years ago, some of them refused to have their fingerprints taken. A number of others, including a few other foreigners from Western countries,

90. Foreigner's Registration Law, Law No. 125, 1952, art. 14.

91. Id. art. 11 (as amended by Law No. 75,1982 ).

92. Pub. L. No. 670, 8 U.S.C.A. $§ 1201$ (b) (1940).

93. The following description in terms of Korean residents applies to Taiwanese residentsmutatis mutandis. 
followed suit and refused to obey the law. Some of them were prosecuted. Wide protest movements in the name of human rights followed not only among Korean residents and other foreigners, but also among Japanese citizens.

The legal position of these protesters was that the fingerprint requirement violated their right to privacy ${ }^{94}$ or, alternatively, that it discriminated against foreigners, particularly against Korean residents. ${ }^{95}$ It was a bit dubious whether either of these constitutional arguments could be successfully maintained, and even more dubious whether the judicial courts would be persuaded by these arguments. While there were a few court decisions, including one of the Tokyo High Court, none showed any sympathy toward a constitutional presentation of the issue. ${ }^{96}$ To the people concerned, however, it did not matter whether their arguments were well constructed on a constitutional basis. To them, their perception that the law was against human rights was enough and should be accepted by all. The fingerprint issue became extremely controversial. ${ }^{97}$

In September 1987, the Diet amended the law and deleted the requirement that fingerprints be retaken every five years. ${ }^{98}$ This was, from the Government's viewpoint, a solution to the human rights controversy. A second aspect in solving this controversy, from the Government's standpoint, took place at the time of Emperor Hirohito's funeral. In February 1989, the Cabinet announced a General Amnesty Order by which all prosecutions against persons refusing to obey the fingerprint law were dropped. ${ }^{99}$

I do not intend to say that this example illustrates a typical case of the Japanese way of solving problems. It does, however, indicate something of the working of human rights ideology in contemporary Japan. ${ }^{100}$

94. Today, it is generally understood that Article 13 of the Constitution guarantees the right to privacy, whatever that right may be.

95. The legal status of Korean residents in Japan is a complex issue. For our purposes, however, suffice it to say that before the war their nationality was Japanese.

96. E.g., 1287 Hanrei Jihō 158 (Tokyo Dist. Ct., Jan. 29, 1988); 1285 Hanrei Jihō 152 (Yokohama Dist. Ct., Kawasaki Br., Nov. 18, 1987); 1179 Hanrei Jihō 156 (Fukuoka Dist. Ct., Ogura Br., Aug. 23, 1985); 1125 Hanrei Jihō 96 (Tokyo Dist. Ct., Aug. 29, 1984); 1125 Hanrei Jihō 96 (Yokohama Dist. Ct., June 14, 1984), aff'd 1208 Hanrei Jihō 66 (Tokyo Dist. Ct., Aug. 25, 1986).

97. In the meantime, the issue became a matter of discussion between the Japanese Government and the Government of the Republic of Korea.

98. Law No. 107, 1987.

99. Cabinet Order No. 27, 1989. To the protesters, Hirohito was a symbol of all racial discrimination, especially in terms of discrimination against Koreans. So, the amnesty in memory of Hirohito was hypocritical and as such was hardly acceptable. Some of the accused attempted to continue arguing their cases in court. The Tokyo High Court was confronted with one such case. The Yokohama District Court had dismissed the indictment of a Korean who refused fingerprinting on the basis of the aforementioned Amnesty Order, but the defendant appealed the case, seeking a declaration that he was not guilty. The Tokyo High Court, however, dismissed the appeal for the same reason as the District Court, without considering the merits of the case. 1320 Hanrei Jiho 165 (Tokyo H. Ct., July 6, 1989). The way the case was handled reminds the author of the "Placard" decision in 2 Keishü 529 .

100. In the context of the public sentiment originating from the Constitution, it is appropriate to touch on the idea of "pacifism," which, of course, originates from, or is symbolized in, Article 9, which renounces war. It has long been said that Article 9 became devoid of substance after it could not prevent the Government from establishing the Self-Defense Forces. This, however, is an 
In connection with the public sentiment, some mention should be made of the working of the mass media. Generally, the media world is very much in favor of protecting citizens' rights and covering constitutional issues extensively. Most of the media, including the otherwise conservative sections, are usually critical of the Supreme Court's decisions. It might be said that the mass media tend, if not intentionally, to serve as a counterbalance to the negativist approach of the Supreme Court. While some Supreme Court justices are usually extremely reluctant to declare laws unconstitutional, some of them are willing to express an advisory comment in their concurring opinions suggesting that the legislation in dispute be revised. ${ }^{101}$ Interestingly, the mass media are often inclined to highlight such advisory comments. Neither the press nor the general public is ready to distinguish between the authoritative opinion of the Court and the more extrajudicial comments of individual justices. As a result, the citizenry is left with an impression that the Court is doing something to protect citizens' rights.

Finally, but not exhaustively, I would like to give some attention to the legislative process in Japan. Because of the long tradition of the supraparty Cabinet, almost all meaningful legislation is made under Cabinet responsibility. Of course, legislation by House members, especially by LDP members, takes place on occasion, but it is quite limited. Further, its quality and significance is usually not that of Cabinet legislation. Cabinet legislation is basically made as follows: Drafts are prepared by government ministries and agencies, and before submission to the majority party committee for review, the drafts undergo a strict examination by the Cabinet Bureau of Legislation, a unique group of highly competent experts on legal technicalities who scrutinize the compatibility of draft bills with the existing legal system and make recommendations for modifications necessary to avoid having the new laws later judged unconstitutional by the Supreme Court. This system of screening by the Cabinet Bureau of Legislation is not provided for in the Constitution.

Such recent confrontational bills as the bill demanding governmental support of Yasukuni (Shinto) Shrinel02 or the bill protecting military secrets ${ }^{103}$ were presented to the Diet by a conservative group of the LDP. It is unclear whether the majority asked the Cabinet to take responsibility for

oversimplification. Article 9 still functions in various, but not strictly legal, ways. For instance, it continuously fosters a pacifist ideology among the people, and it serves to hinder or to minimize the enactment of special laws for the military powers. An example of this ideology is the fact that we have had no special legislation protecting military secrets. In a way, Article $\mathbf{9}$, together with the pacifist public sentiment, has contributed to protect civil liberties in Japanese society.

101. See, e.g., the concurring opinions in Oshima v. Hamiguchi, 39 Minshū 247 (Sup. Ct., G.B., Mar. 27, 1985) (a case on the constitutionality of the Income Tax Law); 38 Minshū 1308.

102. The bill was proposed by some LDP members for the first time to the 61st Diet in June 1969. Since then, they have presented similar bills five times. The Diet has not, however, substantively discussed any of the bills.

103. The bill, commonly called the Spy Protection Bill, was introduced to the 102nd Diet in June 1985. But the Diet session terminated at the end of the year without carrying the bill over to the next session. As a result, the bill was dropped with no chance for parliamentary debate. Since then, there has been no indication of anyone reintroducing a similar bill. 
making any of this legislation. In any event, it seems very unlikely that any government ministry or agency, or the Cabinet Bureau of Legislation, would be willing to take the initiative in preparing such a bill.

In fulfilling their mandate to assure that new bills do not contradict the existing order of constitutional law, bureaucrats are, if only incidentally, taking part in the protection of citizens' rights.

\section{VI}

\section{Conclusion}

Japan was the first country in Asia to have a written constitution in late nineteenth century. The Constitution was given to the people from above in the name of the tenno. The aim of making the Constitution was to moderate his state. The modernization was imperative in order to persuade the Western countries to revise the unfair and discriminatory treaties that had been negotiated between these Western countries and Japan in the Tokugawa Shogunate in the 1850 s and 1860 s.

Legal positivism prevailed in the Western world in that period, and aspirations for constitutionalism once prevalent during the revolutionary era at the end of the eighteenth century had already been swept away by that time. The Meiji Constitution was completed in such an ideological atmosphere. It is not surprising that leaders of the Western countries seemed rather tolerant of Schein-Konstitutionalismus, or pseudo-constitutionalism, which was easily identifiable in the Meiji Constitution.

However "pseudo" it might be, Japan could not avoid introducing a certain degree, or some appearance, of authentic constitutionalism in one way or other. Thus, two conflicting views were embedded in the Constitution: one for demanding a strong, authoritarian state based on a sort of divine theory of the tenno regime, and the other calling for real modernization of the society on the basis of something akin to world universalism.

Various reflections of these two views appeared and disappeared one after another during its fifty-five year history. One thing is clear, however: Under the Meiji Constitution, true, unreserved democracy could not be attained. As a matter of fact, the very word "democracy" was not permissible because it sounded repugnant to the tenno's sovereignty. Democracy as well as the meaningful safeguard of civil liberties remained to be achieved in the unforeseeable future when Japan would have an utterly new Constitution.

The new Constitution was promulgated and enacted in 1946-1947 as a result of Japan's defeat in World War II. By having the present Constitution, Japan again became the first country in Asia to have a constitution of almost unreserved democracy. ${ }^{104}$ Japan declared that it was founded upon a "principle of mankind." 105

104. The degree of "unreservedness" is dependent upon one's evaluation of the interposition of the tennō system.

105. 1947 Const. preamble, $\uparrow 1$. 
Japan's process of democratization is still going on. There remains a lot of unfinished business. One indication of its incompleteness is that there has been no turnover of the reins of government since 1955 when a newly set-up conservative party, the LDP, ascended to power. Whatever may be the reasons for one party's continuation in power for thirty-five years, such a phenomenon of power monopoly should be regarded as anomalous to democracy. This anomaly is, however, due to matters of politics and to the political judgments of the people; nobody can claim it results from defects in the Constitution. On the contrary, the Constitution opens every possibility for the turnover of administrations. The current anomaly may therefore be expected to be overcome in the future.

With the present Constitution, Japan adopted for the first time in her history a constitution of judicial enforceability. The new experience in this respect is especially important to safeguarding the bill of rights. The idea of legally protected "fundamental human rights" has greatly affected the Japanese way of thinking. But, partly because of the traditional, narrow concept of judicial power, and partly because of bureaucratization of the Supreme Court (as well as many other factors), the development of judicial review of constitutionality is very slow and limited-at least in the eyes of American lawyers. Once, twenty-five years ago, the late Professor Nathanson described the then-prevalent trend of judicial review in Japan like this: "It is obvious that the Supreme Court has not been in the forefront of the fight for the realization of civil liberties in Japan. While it has generally paid lip service to the principles of Chapter III (Rights and Duties of the People) of the Constitution, it has not struck any resounding blows for their effective implementation." 106 His observation was absolutely right, not only in the context of what had happened by the middle of the 1960s, but also in the context of the situation from then on.

This does not necessarily mean that our Supreme Court has lost its raison d'etre and proved itself meaningless. Although it is undeniable that our system of judicial review does not function in the way that its counterpart in the United States does, it is certain that this system, together with the very declaration of the bill of rights, is taken seriously and as such affects in some manner-obviously in an extralegal way-the social and political life of the people.

At the moment, I cannot systematically describe and clearly evaluate what constitutes the characteristics of the function (instead of the text) of the Japanese Constitution and whether these characteristics, if any, bode well or ill for the future of Japan. Nevertheless, I am somehow rather more optimistic than pessimistic about the healthy development of modern constitutionalism in Japan-on the condition that she will not confront an unexpected, extraordinary crisis, either political or economic, in or out of the country's domain.

106. Nathanson, Human Rights in Japan Through the Looking Glass of the Supreme Court Opinions, 11 HoWARD L.J. 318, 323 (1965). 
$$
\text { . }
$$ 